\title{
Utilization of lung cancer cell lines for the study of lung cancer stem cells (Review)
}

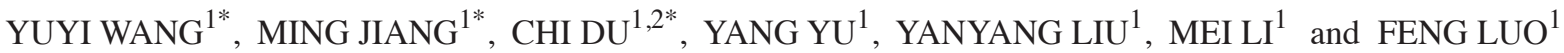 \\ ${ }^{1}$ Department of Medical Oncology, Cancer Center, Lung Cancer Center and State Key Laboratory of Biotherapy, \\ West China Hospital of Sichuan University, Chengdu, Sichuan 610041; ${ }^{2}$ Department of Oncology, \\ The Second People's Hospital of Neijiang, Neijiang, Sichuan 641000, P.R. China
}

Received July 29, 2015; Accepted March 30, 2017

DOI: $10.3892 / \mathrm{ol} .2018 .8265$

\begin{abstract}
Lung cancer is one of the most lethal types of cancer, and its poor prognosis is primarily due to drug resistance and cancer recurrence. As it is associated with a low five-year survival rate, lung cancer stem cells (LCSCs) have been the subject of numerous recent studies. For these studies of LCSCs, lung cancer cell lines are more commonly used than lung cancer tissues obtained from patients, as they are easier to acquire. The methods utilized for the identification of LCSCs from lung cancer cell lines include fluorescence activated cell sorting (FACS), magnetic activated cell sorting (MACS), sphere-forming assay and bacterial surface display library screening. As LCSCs have certain proteins expressed on the surface (CD133, CD44 and CD24) or in the cytoplasm (ALDH and ABCG2), which may act as specific markers, the most frequently used technique to identify and obtain LCSCs is FACS. The current lack of recognized biomarkers in LCSCs makes the identification of LCSCs problematic. Furthermore, the various proportions of LCSCs in specific cell lines, as revealed by numerous previous studies, may cause the LCSC model to be questioned with regard to whether the utilization of certain lung cancer cell lines is dependable for LCSC studies. The current review focuses on lung cancer cell lines that are used for the study of LCSCs and the methods available to identify LCSCs with various markers. The present study also aimed
\end{abstract}

Correspondence to: Dr Feng Luo, Department of Medical Oncology, Cancer Center, Lung Cancer Center and State Key Laboratory of Biotherapy, West China Hospital of Sichuan University, 37 GuoXue Lane, Chengdu, Sichuan 610041, P.R. China E-mail: luofeng@medmail.com.cn

${ }^{*}$ Contributed equally

Abbreviations: LCSCs, lung cancer stem cells; BASCs, bronchio alveolar stem cells; FACS, fluorescence activated cell sorting; MACS, magnetic activated cell sorting; ALDH, acetaldehyde dehydrogenase

Key words: lung cancer, cancer cell line, cancer stem cell, marker, proportion to determine the proportion of LCSCs present in specific cell lines reported by various studies, and to discuss the suitability of specific lung cancer cell lines for the study of LCSCs.

\section{Contents}

1. Introduction

2. Lung cancer and LCSCs

3. Lung cancer cell lines are used for studies of LCSCs

4. Methods of the identification and collection of LCSCs in lung cancer cell lines

5. Protein markers used for the identification and sorting of LCSCs

6. Significant difference in the proportion of LCSCs in lung cancer cell lines

7. Controversies within the study of LCSCs in lung cancer cell lines

8. Are protein markers dependable tools for the identification of LCSCs?

9. Conclusion

\section{Introduction}

Lung cancer stem cells (LCSCs) have an important role in the development of lung cancer; therefore, LCSCs have been the subject of numerous recent studies (1-3). According to certain studies, LCSCs originate primarily from normal tissue stem cells or the de-differentiation of normal cancer cells $(3,4)$. Prior investigations of LCSCs have been conducted using cancer cell lines or patient primary tumor tissue samples, of which, the former is more often used due to easier access. LCSCs are promising targets for lung cancer therapy, and it is crucial to improve available techniques for their identification from normal cancer cells. The current methods of LCSC collection include fluorescent activated cell sorting (FACS), magnetic activated cell sorting (MACS), sphere-forming assay, the establishment of lung cancer cell lines with stem cell properties and bacterial surface display library screening. Among these, FACS is the most commonly used technique. Consequently, the specific markers for isolating LCSCs became the subject of a number of studies (5-11). ATP binding cassette superfamily $\mathrm{G}$ member 2 (ABCG2), acetaldehyde dehydrogenase 
(ALDH), CD133, CD166, CD44, C-X-C chemokine receptor type 4 (CXCR4) and interleukin-6 receptor (IL-6R) and other proteins (as shown in Table I) have all previously been identified as markers of LCSCs, and these markers may be utilized in further studies to identify LCSCs.

\section{Lung cancer and LCSCs}

Lung cancer is the most frequent cause of cancer-associated mortality (12) and $\sim 1.4$ million individuals succumb to the disease annually (13). There are two major types of lung cancer: Small cell lung cancer (SCLC), which accounts for $\sim 15 \%$ of all types of lung cancer (14) and non-small cell lung cancer (NSCLC), which accounts for $~ 80 \%$ of all lung cancer cases (15). NSCLC maybe further divided into two subtypes: Squamous cell carcinoma (30\% of NSCLC cases) and adenocarcinoma (70\% of NSCLC cases) (13). A good prognosis is typically predicted if the patients are diagnosed at a relatively early tumor stage [according to the National Comprehensive Cancer Network (NCCN) guidelines] $(16,17)$. However, it is well-known that a number of cases are diagnosed at the third or fourth NCCN stage and are associated with a poor survival rate due to inefficacious treatment options. Studies on poor clinical outcomes identified that the complex tumor microenvironment, particularly of CSCs, is involved in the promotion of tumor metastasis (18), drug resistance (19) and resistance to radiotherapy (20).

The CSC model was first proposed in 1997 following the identification of leukemia stem cells (21), and evidence for the existence of LCSCs was presented by Giangreco et al (22) in 2009. The properties of LCSCs include: Drug resistance, self-renewal and the capacity to form tumors in xenograft mouse models. These features are the current gold standard for the identification of human LCSCs (23). Other criteria used to identify CSCs are as follows: CSCs sorted by FACS are able to generate spheres in non-adherent cultures; more aggressive metastatic properties determined using a Transwell assay; the formation of CSC colonies is efficient, as compared with normal cancer cells; certain mRNAs and proteins, including octamer-binding transcription factor 4 (OCT4), homeobox protein NANOG and sex-determining region Y HMG-box 2 (SOX2) that are associated with cancer stem cells are overexpressed (24).

The origin of CSCs is still a matter of debate; the two hypotheses of CSC sources are presented in Fig. 1. For LCSCs, the possibility of their origin from normal tissue stem cells was proposed by a previous study (25). A pulmonary stem cell population was initially identified at the bronchio alveolar duct junction and termed bronchio alveolar stem cells (BASCs), on account of the stem cell-like features (26). Transformation of BASCs to normal lung cancer stem cells is induced by various carcinogenic factors; it is also possible for BASCs to transform to LCSCs (26). Additionally, it has been reported that LCSCs may develop from normal cancer cells that have regained a capacity for self-renewal following de-differentiation to a progenitor-like state (27).

\section{Lung cancer cell lines are used for studies of LCSCs}

Prior investigations into LCSCs have been primarily conducted using various cancer cell lines or primary patient tissue samples $(28,29)$. Studies of LCSCs using patient tissue samples are the gold standard; however, these are difficult to regularly obtain (30) and tissue samples from patients with early NCCN stage cancer often possess varying quantities of non-malignant cells (31). Therefore, lung cancer cell lines are more often used to study LCSCs, rather than patient tumor tissues.

In the present study, the American Type Culture Collection (ATCC, Manassas, VA, USA) was searched for lung cancer cell lines, with a total of 213 subsequently presented. The number of individual lung cancer cell lines is almost the largest amongst epithelial cancer cell types, and $20 \%$ of cancer cell lines in the Sanger database (www. sanger. ac. uk) are of lung cancer origin (32). The establishment of cancer cell lines begins with the dissociation of tumor tissues using trypsin, following which the dispersed cells are cultured on plates (33). A minority of cells are able to proliferate and form colonies followed by several divisions, whereas other cells undergo apoptosis (34). These colony-forming cells undergo a limited number of further divisions and subsequently lose their ability to undergo mitosis. A few cells, however, are able to overcome the Hayflick limit and become immortal cancer cell line (34).

\section{Methods of the identification and collection of LCSCs in lung cancer cell lines}

FACS and MACS. FACS is the most widely used technique for the identification and sorting of LCSCs (5). Specific monoclonal antibodies, each of which is highly specific for the target antigen and are readily coupled to fluorescein, phycobiliproteins or other fluorochromes (6), combine with LCSC protein markers on the cell surface or in the cytoplasm. Subsequently, the cells that express these markers can be selected (5). Single-cell sorting using FACS is the most efficient method currently available, particularly when the cells are present in low quantities (6). MACS is also utilized for the sorting of LCSCs. Compared with FACS, MACS is typically faster for sorting low-abundance cell populations (7). As the aim is to identify cancer stem cells that account for low proportion of all cancer cells, MACS maybe more efficient compared with FACS despite the higher cost (to use MACS, more tools are necessary compared with FACS, such as the expensive magnetic bead).

Sphere-forming assay. As aforementioned, sphere forming is one of the properties of LCSCs, and the enrichment of LCSCs using this assay method has been used (8). When cultured in serum-free medium (DMEM/F12 medium) supplemented with basic fibroblast growth factor and epidermal growth factor, lung cancer stem cells are able to form floating spheres, and CSCs are enriched inside these spheres (8).

Establishment of lung cancer cell lines with stem cell properties. Human bronchial epithelial cells retain the capacity to differentiate into basal, mucin-producing and columnar ciliated epithelial cells; therefore, they may be used for the study of CSCs (9). A previous study established a cell line as a CSC line by sorting $\mathrm{CD} 133^{+}$cells from fresh human lung cancer tissue samples using MACS and subsequently culturing them in serum-free medium (10). 
Bacterial surface-display library screening. For this method, CSCs are enriched using the aforementioned sphere-forming assay. The spheres are dissociated into single cells for incubation with a bacterial library, and are then able to express green fluorescent protein (GFP) and not bind to the differentiated cells. FACS is used to identify cells expressing GFP, which facilitates the selection of cells with fluorescein isothiocyanate (FITC) fluorescence (11).

\section{Protein markers used for the identification and sorting of LCSCs}

As aforementioned, FACS is the major method currently used for LCSC identification and sorting; the markers used for their isolation have been the focus of various studies $(33,35-37)$. It is possible to identify LCSC by staining cells using antibodies against these specific markers, and then to sort them using flow cytometry (35-37). These markers include: CD133, CD166, CD44, CXCR4 and IL-6R. Combined markers are also used, including CD133 and CD44, CD44 and CD24, CD166 and Lin, CD133 and CD326, CD133 and CD338 (Table I). These are markers expressed on the surface of lung cancer cells or inside these cells; the majority are functional enzymes, including ALDH, HO and GLDC (Table I). The present review discusses three primary LCSC markers, including ATP-binding cassette sub-family G member 2 (ABCG2), aldehyde dehydrogenase (ALDH) and CD133.

$A B C G 2$. A side population (SP) is a group of cells with $\mathrm{ABC}$ transporters responsible for the efflux of drugs and drug-like dyes (Hoechst 33342), which are able to protect the CSCs from certain cytotoxic agents (38). The cells with $\mathrm{ABC}$ transporter pumps were initially isolated by flow cytometry as an SP (39), and numerous studies have demonstrated that SPs exhibit stemness (Table I). A previous study on SCLC revealed that SP cells are highly tumorigenic, exhibiting drug resistance features and the expressing certain stem cell genes (40). However, SP cells may not consist entirely of stem cells as other types of cells are also able to eliminate the Hoechst dye, and the SP phenotype is affected by staining time, dye concentration and cellular concentrations (41). In addition, cytometry gating strategies used to isolate SP cells lack the consistency of gating strategies used when staining with markers (41).

$A L D H$. ALDH has been used as a protein marker of LCSCs by large number of recent studies (Table I). Cells with high levels of ALDH are considered to be LCSCs due to a number of their characteristics including self-renewal, differentiation capacity, drug resistance, expression of other LCSC markers and positive results following xenotransplantation into mice; a small number of ALDH ${ }^{\text {high }}$ cells, identified and separated with FACS, was demonstrated to lead to successful growth of cancer (42). Certain prior studies have also used a combination of ALDH and other surface markers to identify LCSC, including $\mathrm{ALDH}^{+} \mathrm{CD} 44^{+}$(43). However, Okudela et al (44) demonstrated the presence of an inverse association between ALDH1A1 expression levels and tumor aggressiveness. ALDH1A1 expression levels were identified to be decreased amongst smokers and patients with poorly differentiated adenocarcinoma and large cell carcinoma, which suggests that

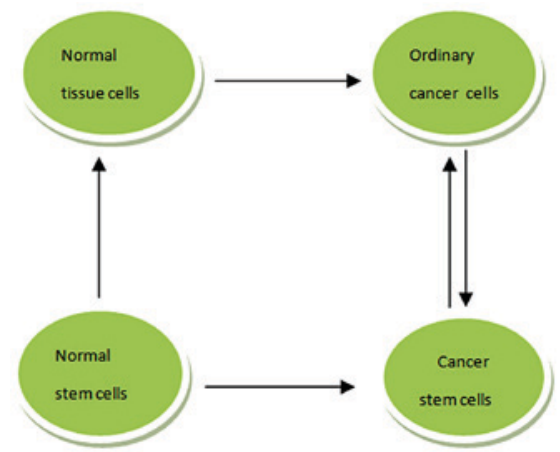

Figure 1. Origination of cancer stem cells: Normal stem cells will differentiate into normal tissue cells and normal tissue cells can transform into ordinary cancer cells. Cancer stem cells originate from the transformation of normal stem cells and de-differentiation of normal cancer cells.

the functional properties of LCSCs may not be sufficient as independent markers for identifying stem cells (1).

CD133. To the best of our knowledge, CD133 was the first LCSC marker identified; however, whether CD133 may be utilized as a marker of LCSCs is under debate. Meng et al (45) revealed that $\mathrm{CD}_{133^{+}}$and $\mathrm{CD} 133^{-}$and subpopulations of A549 and H446 cells contain cancer-initiating cells. Furthermore, $\mathrm{CD}_{133^{+}}$cells have been identified in normal tissues, including bone marrow (46).

In fact, a well-accepted marker for a certain cell line, such as A549, does not exist. It has been demonstrated that $\geq 3$ specific stem cell markers, alone or combined, including $\mathrm{ALDH}^{+}$, $\mathrm{CD} 33^{+}, \mathrm{CD}^{2} 0^{+}(2), \mathrm{IL}-6 \mathrm{R}(24), \mathrm{OCT}-4$ (47), CD $44^{+} \mathrm{CD} 24$, $\mathrm{CD} 133^{+} \mathrm{CD}_{44} 4^{+}(48), \mathrm{CD} 133{ }^{+} \mathrm{CD} 326^{+} / \mathrm{CD} 133{ }^{+} \mathrm{EpCAM}^{+}$, $\mathrm{CD} 33^{+} \mathrm{CD} 338^{+} / \mathrm{CD} 133^{+} \mathrm{ABCG} 2^{+}$may be useful candidate markers for identification of LCSCs (Table I).

Once specific markers have been identified as useful for classifying stem cells in other types of cancer, they may subsequently be used for LCSC sorting. It must be considered whether the cells that were sorted with various markers are actually the stem-like cells sought if they exhibit characteristics previously assumed to be exclusively associated with stem cells. If so, it is essential to identify those markers that may be the most useful as this will form the foundation for further studies.

\section{Significant differences in the proportion of LCSCs in lung cancer cell lines}

In the present review, markers of LCSCs previously presented by various studies were evaluated (Table I). The present study identified that the proportions of LCSCs in the same lung cancer cell line sorted with different markers are not the same, and the proportion of LCSCs differs in the same cell line even the same marker used, after analysis of a number of studies. Specifically, the proportion of LCSC is $\leq 7 \%$ with 'SP', $0.76 \%$ with $\mathrm{CD} 44^{+} \mathrm{CD} 24$ - and $2.5 \%$ with $\mathrm{CD} 133$. CD133 ${ }^{+} \mathrm{LCSCs}$ counts for $\sim 0.3 \%$ as reported by Yi et al (47); however, Tirino et al (27) demonstrated that the proportion of LCSCs observed in the same cell line was $\geq 10$ times higher, at $~ 3.9 \%$.

Roudi et al (49) studied expression of several CSC markers of A549 cells and their result showed that $\sim 68.16$ or $54.46 \%$ of the cells expressed CD44 or CD24, 27.92\% cells express 
Table I. Ratios of LCSCs in lung cancer cell lines reported in various studies.

\begin{tabular}{|c|c|c|c|c|}
\hline Cancer type & Cell line & Marker & Proportion of cell line $(\%)$ & (Refs.) \\
\hline \multirow[t]{53}{*}{ NSCLC } & A549 & SP & 18.1 & $(48)$ \\
\hline & & & 16.82 & $(47)$ \\
\hline & & & 2.55 & $(84)$ \\
\hline & & & $\sim 4$ & $(49)$ \\
\hline & & & 0.9 & $(50)$ \\
\hline & & & 24 & $(51)$ \\
\hline & & & $2-4$ & $(40)$ \\
\hline & & & $4-10$ & $(65)$ \\
\hline & & IL-6R & 1.4 & $(47)$ \\
\hline & & D133 & 0.3 & $(47)$ \\
\hline & & & $\sim 0.5$ & $(70)$ \\
\hline & & & 3.9 & $(27)$ \\
\hline & & & 2 & $(71)$ \\
\hline & & & 0.2 & $(72)$ \\
\hline & & & $0.3-1$ & $(65)$ \\
\hline & & $\mathrm{CD} 133^{+} \mathrm{CD} 328^{+}$ & / & $(73)$ \\
\hline & & & 0.93 & $(49)$ \\
\hline & & $\mathrm{CD} 133^{+} \mathrm{CD} 326^{+}$ & 0.14 & $(74)$ \\
\hline & & & 0.25 & $(75)$ \\
\hline & & ALDH & / & $(76)$ \\
\hline & & & 4.2 & $(49)$ \\
\hline & & & $2-8$ & $(65)$ \\
\hline & & $\mathrm{CD}_{4} 4^{+} \mathrm{CD} 24^{-}$ & 27.92 & $(49)$ \\
\hline & & $\mathrm{CD} 166^{+} \mathrm{CD} 44^{+}$ & 62.5 & $(77)$ \\
\hline & & $\mathrm{CD}_{166^{+} \mathrm{CD} 326^{+}}$ & 9.8 & (77) \\
\hline & H1650 & SP & 7 & $(78)$ \\
\hline & & $\mathrm{CD} 44^{+} \mathrm{CD} 24^{-}$ & 0.76 & $(78)$ \\
\hline & & CD133 & $\sim 2.5$ & (78) \\
\hline & $\mathrm{H} 460$ & SP & l & $(67)$ \\
\hline & & & 24.19 & $(47)$ \\
\hline & & & 5.2 & $(79)$ \\
\hline & & & 5.6 & (69) \\
\hline & & & 3.5 & $(80)$ \\
\hline & & & $2-4$ & $(40)$ \\
\hline & & IL-6R & 0.04 & $(47)$ \\
\hline & & CD133 & 0.82 & $(47)$ \\
\hline & & & 1.1 & (81) \\
\hline & & ALDH & $\sim 3$ & (42) \\
\hline & $\mathrm{H} 23$ & SP & 77.25 & (47) \\
\hline & & & $\sim 1.5$ & (69) \\
\hline & & IL-6R & 0.74 & (69) \\
\hline & & CD133 & 0.17 & (69) \\
\hline & H522 & ALDH & 29.66 & $(26)$ \\
\hline & H1299 & CD44 & 81.3 & (56) \\
\hline & H322 & ALDH & 0.6 & $(42)$ \\
\hline & H125 & ALDH & 2.9 & (42) \\
\hline & H358 & ALDH & 2.82 & (42) \\
\hline & HCC827 & $\mathrm{ALDH}^{+} \mathrm{CD} 44^{+}$ & 3.04 & (43) \\
\hline & & SP & 1.9 & (82) \\
\hline & H1975 & SP & I & (67) \\
\hline & H441 & SP & $\sim 6.1$ & (68) \\
\hline & & & $0.5-3$ & $(65)$ \\
\hline & & CD133 & $0.1-0.5$ & $(65)$ \\
\hline
\end{tabular}


Table I. Continued.

\begin{tabular}{|c|c|c|c|c|}
\hline Cancer type & Cell line & Marker & Proportion of cell line (\%) & (Refs.) \\
\hline & & ALDH & $0.5-2$ & $(65)$ \\
\hline & H661 & CD133 & $\sim 5.3$ & $(81)$ \\
\hline & H2170 & & $\sim 2.5$ & $(69)$ \\
\hline & PC-9 & SP & 2.6 & $(68)$ \\
\hline & LHK2 & SP & 2.8 & $(50)$ \\
\hline & COR L23 & $\mathrm{CD} 44^{+} \mathrm{CD} 24^{-}$ & 0 & (83) \\
\hline \multirow[t]{3}{*}{ SCLC } & Lc817 & SP & 0.4 & $(50)$ \\
\hline & H146 & SP & $\sim 0.8$ & $(40)$ \\
\hline & H526 & SP & $\sim 0.9$ & $(40)$ \\
\hline \multirow[t]{4}{*}{$\mathrm{SCC}$} & HTB58 & SP & $\sim 4.5$ & (69) \\
\hline & $1-87$ & SP & 0.8 & $(50)$ \\
\hline & H2170 & $\mathrm{CD} 166^{+} \mathrm{CD} 44^{+}$ & 0 & $(77)$ \\
\hline & & $\mathrm{CD} 166^{+} \mathrm{CD} 326^{+}$ & 3.1 & $(77)$ \\
\hline
\end{tabular}

NSCLC, non-small cell lung cancer; SCC, squamous cell carcinoma; LCSC, lung cancer stem cells; SP, side population; CD, cluster of differentiation; ALDH, acetaldehyde dehydrogenase.

$\mathrm{CD} 44^{+} \mathrm{CD} 24^{-/ \text {low }}$. This study also evaluated that the proportion of $\mathrm{ALDH}^{+}$cells was $\sim 4.20 \%$, while the proportion of $\mathrm{ABCG}^{+}$or $\mathrm{CD} 133^{+}$cells was $\sim 0.93 \%$. CD $44^{+} / 133^{+}$populations were rare. It must be investigated why the proportion of LCSCs within cell lines can vary so significantly.

Proportions of LCSCs in certain cell lines identified with the same markers may vary, partly due to the distinct environment of each cell population. Furthermore, the LCSC proportion within specific cells lines may also vary. Cell lines are established through single cell separation and cultivation; during the cell lifetime, the manifestations of its phenotype and protein expression profile must be observed as once a cell line is grown it acquires mutations, including chromosome loss or gain. Although cell lines used in the laboratory are originally identical, they may experience significant differences in cell passage number, the medium used, the microenvironment, which may specifically affect the stem cell proportion, and how they are maintained; therefore, numerous cell features, including the cell charge, which may affect the electrophoresis potential, and the chromosome number, may be inconsistent. The SP cell ratio may range from $0.9-24 \%$ in the A549 cell line according to the results of two independent studies $(50,51)$. Genetic or epigenetic changes in cancer cells are necessary, in vivo and in vitro, in order to allow the cells to adapt to the conditions to which they are exposed (52). For example, hypoxic conditions lead to the selection of a hypoxia-resistance phenotype for cancer stem cells (53). The high proportion of LCSCs identified in A549 cells identified by Sung et al (51) may be due to the A549 cell lines they employed, which are likely to undergo more rigorous conditions of existence, such as less supplements and hypoxia. Studies using other types of cancer cells have also indicated that, while the microenvironment conditions can lead to the loss of stemness in CSCs, glioma cell lines may lose their multi-potential differentiation capability and the expression of certain stem cell markers when cultured even under standard conditions (54).
CSCs are considered to be a small subpopulation of cells, typically $\leq 1 \%$ within a given tissue (55); however, numerous studies have identified a varying proportion of normal cancer cells. According to a study conducted by Meng et al (45), $\geq 45 \%$ of A549 and H446 cells are cancer-initiating cells. Using flow cytometry, Leung et al (56) investigated the expression of specific proteins considered to be markers of LCSCs in ten lung cancer cell lines, including CD34, CD44, CD133, BMI1 and OCT4 (56). The results indicated that $\mathrm{CD}_{133^{+}}$cancer cells were rare in those cell lines, and CD133 ${ }^{+}$cancer cells were only identified in the HCC1833 cell line. CD $44^{+}$cancer cells, as determined by the authors (56), 'are enriched for stem cell-like properties' and counted for $61.7-95.9 \%$ in H1650, H1299, HCC827 and H23 cells. Therefore, a high proportion of cells in these lines have stem cell-like properties, which indicates that the majority of these cells are LCSCs.

Possible explanations for the higher proportion of CSCs observed in certain studies may include the aforementioned harsh living conditions and an extended culture duration. As previously established, when cancer cells are cultured for a relatively long time, the majority will die and a fraction will survive and become immortal cancer cells (53). The current definition of cancer stem cells refers them as a subpopulation of cells within tumors that do not have a growth limit and are the only tumorigenic cells among all other tumor cell subsets. The longer the culture duration, the higher the probability that stem cells will be selected to survive, and a subsequently higher percentage of stem cells within a cell population may be observed (57).

\section{Controversies within the study of LCSCs in lung cancer cell lines}

Whether lung cancer cells are suitable and dependable for the study of LCSCs is a matter of debate. Certain studies have hypothesized that distinction between lung cancer cell lines and lung cancer tissues still remains. The results of clinical 
trials of treatments for patients with lung cancer may occasionally differ from the results obtained in studies on lung cancer cell lines. For example, cell lines are utilized in studies evaluating treatments targeting cancer stem cells; those agents that were observed to be effective during experiments using cancer cell lines did not exhibit a corresponding efficacy in vivo in patients with cancer, due to the differences between cancer cell lines and cancer tissues in vivo. Although complete response (CR) has been observed in a proportion of patients, a large quantity of diverse cancer cells may still remain, often $\geq 1 \times 10^{9}(58)$. The mutation rate in intra-tumoral types of cancer is usually between $1 \times 10^{-8}-1 \times 10^{-9}$ per base per cell division, and this can result in mutations arising in numerous cancer cells (59). For example, genes concerning stemness in specific cells are activated and this is the source of the changes via which normal cancer cells become cancer stem cells. Cancer cell lines are typically more stable, with a mutation rate relatively lower than that identified in cancer tissues; this may partly explain the failure of clinical agents targeting cancer stem cells that originated and were developed from studies that utilized cancer cell lines.

Shortcomings of using lung cancer cell lines for the study of LCSCs originate from the differences between cancer cell lines and cancer tissues. As compared with tumor cells in tissues, tumor cell lines are usually cultured in flasks or dishes in $2 \mathrm{D}$, which may result in changes in gene expression, cell morphology and chromatin condensation (60). As reviewed by Gazdar et al (61), there are four principal disadvantages of using lung cancer cell lines for the study of lung cancer, including the following: The possible selection of minor tumor cell subpopulations that may not be representative of the original population; the potential acceleration of genomic instability; the absence of stromal, immune and inflammatory cells; the absence of vascularization; difficulty in evaluating the metastatic potential. Other limitations include alterations in the DNA (62) and mRNA (63). Standard culture protocols may lead to the selective growth of rapidly growing cells that may have more molecular abnormalities than other tumor cells (61). For example, lung carcinoma cell lines have extensive chromosomal rearrangements, oncogene mutations and multiple sites of allelic loss and gene amplification (64).

Through reviewing and summarizing a number of studies on LCSCs conducted during recent years, it was revealed that the majority of studies utilized adenocarcinoma cell lines, particularly the A549 cell line, to investigate LCSCs (presented in Table I). Therefore, our current understanding of LCSCs has been derived from information obtained using only a select few cell lines, which cannot be assumed to represent the various cancer cells present in lung cancer tissues.

\section{Are protein markers dependable tools for the identification of LCSCs?}

CSCs enriched using diverse methods are dissimilar in a number of aspects. One study demonstrated that when $\mathrm{CD}_{133^{+}}$and SP cells sorted from A549 cells were cultured in adherent dishes for 3 weeks with cancer stem cell medium, the $\mathrm{CD}_{133}{ }^{+}$cell subpopulation decreased, while the SP population increased (65). The author also observed that the SP cells positive for ALDH, or CD133 are also present in low numbers. Furthermore, self-renewal and metastatic gene expression patterns were revealed to be distinct between $\mathrm{SP}, \mathrm{CD}_{13}{ }^{+}$and $\mathrm{ALDH}^{\text {high }}$ cells. SP and CD133+ cells demonstrated increased lung colonization, as compared with their negative counterparts, while the injection of ALDH ${ }^{\text {high }}$ cells into xenograft mice induced numerous liver metastases (65). Another phenomenon in which the number of cells sorted within bacterial surface display library screening are CD133 positive at the same time the $\mathrm{H} 460$ cells as described above is very rare, suggesting that there may be no common markers for CSCs (66). Akunuru et al (65) revealed the following: SP and non-SP cells include $\mathrm{CD}_{133^{+}}$or ALDH ${ }^{\text {high }}$ members although non-SP cells express higher levels of each; $\mathrm{ALDH}^{\text {high }}$ and $\mathrm{ALDH}^{\text {low }}$ cells, or SP and non-SP cells, are capable of forming spheres; non-SP cells can generate tumors in immune-compromised NSG mice after 8 weeks (3). These results indicate that cells that are negative for one cancer marker may still be positive for another.

Hypothetically, if LCSCs may be able to differentiate to numerous types of progeny cells and express a variety of markers, and cells with certain markers can be excluded from the leader cells.

\section{Conclusion}

The method most commonly employed to determine if a specific protein can be used as a marker of LSCs includes the following steps: First, utilize the fluorescent antibody corresponding to the target marker to label the cells considered to be stem cells, then sort them using FACS or MACS; second, culture the cells to determine whether they can generate spheres, have the capability of forming clones more effectively compared with normal cells and are more aggressive; third, transplanting CSCs into xenograft mice at a relatively small amount to test the tumorigenicity. Sorting of the CSCs is considered to be the key step, as this technique can distinguish CSCs from normal cancer cells directly.

To the best of our knowledge, there is currently no evidence that any combination of cancer stem-cell markers isolates any cancer stem-cell population to a high degree of purity (46). There are certain problems associated with LCSC studies: Tumor cell lines are used as the principal model in CSC studies, as aforementioned; marker expression and cell subsets may vary within the same cell line, so the results are not directly comparable and cannot be used as a reference; the proportion of LCSCs identified with certain marker expression is inconsistent between and within cell lines, which raises the question of whether those cells are true LCSCs or if they are other cell types with only specific CSC-associated characteristics; the gold standard for the identification of LCSCs includes successful xenotransplantation into immunodeficient mice. However, immune barriers remain in nude mice despite the lack of T cells (66). It is possible that LCSCs have been eliminated by the immune system and the tumor cells derive from daughter cells of LCSCs; the ability of a cell to form a tumor is dependent upon the microenvironment, and cells that can form tumors under one set of conditions may not form tumors under other conditions (4). Therefore, further studies are required. 


\section{References}

1. Singh S and Chellappan S: Lung cancer stem cells: Molecular features and therapeutic targets. Mol Aspects Med 39: 50-60, 2014.

2. Yan X, Luo H, Zhou X, Zhu B, Wang Y and Bian X: Identification of CD90 as a marker for lung cancer stem cells in A549 and H446 cell lines. Oncol Rep 30: 2733-2740, 2013.

3. Akunuru S, James Zhai Q and Zheng Y: Non-small cell lung cancer stem/progenitor cells are enriched in multiple distinct phenotypic subpopulations and exhibit plasticity. Cell Death Dis 3: e352, 2012.

4. Meacham CE and Morrison SJ: Tumour heterogeneity and cancer cell plasticity. Nature 501: 328-337, 2013.

5. Dionne LK, Driver ER and Wang XJ: Head and neck cancer stem cells: From identification to tumor immune network. J Dent Res 94: 1524-1531, 2015.

6. Herzenberg LA, Parks D, Sahaf B, Perez O, Roederer M and Herzenberg LA: The history and future of the fluorescence activated cell sorter and flow cytometry: A view from Stanford. Clin Chem 48: 1819-1827, 2002

7. Xu Y, Zhao W, Wu D, Xu J, Lin S, Tang K, Yin Z and Wang X: Isolation of myeloid-derived suppressor cells subsets from spleens of orthotopic liver cancer-bearing mice by fluorescent-activated and magnetic-activated cell sorting: Similarities and differences. Int J Clin Exp Pathol 7: 7545-7553, 2014.

8. Izumiya M,Kabashima A,Higuchi H,Igarashi T, Sakai G,Iizuka H, Nakamura S, Adachi M, Hamamoto Y, Funakoshi S, et al: Chemoresistance is associated with cancer stem cell-like properties and epithelial-to-mesenchymal transition in pancreatic cancer cells. Anticancer Res 32: 3847-3853, 2012.

9. Vaughan MB, Ramirez RD, Wright WE, Minna JD and Shay JW: A three-dimensional model of differentiation of immortalized human bronchial epithelial cells. Differentiation 74: 141-148, 2006.

10. Kucerova L, Feketeova L, Kozovska Z, Poturnajova M, Matuskova M, Nencka R and Babal P: In vivo 5FU-exposed human medullary thyroid carcinoma cells contain a chemoresistant CD133+ tumor-initiating cell subset. Thyroid 24: 520-532, 2014.

11. Wang A, Chen L, Pu K and Zhu Y: Identification of stem-like cells in non-small cell lung cancer cells with specific peptides. Cancer Lett 351: 100-107, 2014.

12. Schaefer-Prokop C, Prosch $\mathrm{H}$ and Prokop M: Lung cancer screening: What have we learnt for the practice so far? Radiologe 54: 462-469, 2014 (In German).

13. Spira A, Halmos B and Powell CA: Update in lung cancer 2014 Am J Respir Crit Care Med 192: 283-294, 2015.

14. Herbst RS, Heymach JV and Lippman SM: Lung cancer. N Engl J Med 359: 1367-1380, 2008.

15. Anglim PP, Alonzo TA and Laird-Offringa IA: DNA methylation-based biomarkers for early detection of non-small cell lung cancer: An update. Mol Cancer 7: 81, 2008.

16. Ettinger DS, Wood DE, Akerley W, Bazhenova LA, Borghaei H, Camidge DR, Cheney RT, Chirieac LR, D'Amico TA, Demmy TL, et al: Non-small cell lung cancer, Version 6. 2015. J Natl Compr Canc Netw 13: 515-524, 2015.

17. Kalemkerian GP, Akerley W, Bogner P, Borghaei Hossein, Chow LQ, Downey RJ, Gandhi L, P Ganti AK, Govindan R, Grecula JC, et al: Small cell lung cancer. J Natl Compr Canc Netw 11: 78-98, 2013.

18. Mani SA, Guo W, Liao MJ, Eaton EN, Ayyanan A, Zhou AY, Brooks M, Reinhard F, Zhang CC, Shipitsin M, et al: The epithelial-mesenchymal transition generates cells with properties of stem cells. Cell 133: 704-715, 2008 .

19. Bao S, Wu Q, McLendon RE, Hao Y, Shi Q, Hjelmeland AB, Dewhirst MW, Bigner DD and Rich JN: Glioma stem cells promote radioresistance by preferential activation of the DNA damage response. Nature 444: 756-760, 2006.

20. Alison MR, Lin WR, Lim SM and Nicholson LJ: Cancer stem cells: In the line of fire. Cancer Treat Rev 38: 589-598, 2012.

21. Bonnet D and Dick JE: Human acute myeloid leukemia is organized as a hierarchy that originates from a primitive hematopoietic cell. Nat Med 3: 730-737, 1997.

22. Giangreco A, Arwert EN, Rosewell IR, Snyder J, Watt FM and Stripp BR: Stem cells are dispensable for lung homeostasis but restore airways after injury. Proc Natl Acad Sci USA 106: 9286-9291, 2009.

23. Lathia JD, Mack SC, Mulkearns-Hubert EE, Valentim CL and Rich JN: Cancer stem cells in glioblastoma. Genes Dev 29: 1203-1217, 2015
24. Gawlik-Rzemieniewska N and Bednarek I: The role of NANOG transcriptional factor in the development of malignant phenotype of cancer cells. Cancer Biol Ther 17: 1-10, 2016.

25. Fulawka L, Donizy P and Halon A: Cancer stem cells-the current status of an old concept: Literature review and clinical approaches. Biol Res 47: 66, 2014

26. Ucar D, Cogle CR, Zucali JR, Ostmark B, Scott EW, Zori R, Gray BA and Moreb JS: Aldehyde dehydrogenase activity as a functional marker for lung cancer. Chem Biol Interact 178: 48-55, 2009.

27. Tirino V, Camerlingo R, Bifulco K, Irollo E, Montella R, Paino F Sessa G, Carriero MV, Normanno N, Rocco G and Pirozzi G: TGF- $\beta 1$ exposure induces epithelial to mesenchymal transition both in CSCs and non-CSCs of the A549 cell line, leading to an increase of migration ability in the CD133+ A549 cell fraction. Cell Death Dis 4: e620,2013.

28. Ahmadipour F, Noordin MI, Mohan S, Arya A, Paydar M, Looi CY, Keong YS, Siyamak EN, Fani S, Firoozi M, et al: Koenimbin, a natural dietary compound of murraya koenigii (L) spreng: Inhibition of MCF7 breast cancer cells and targeting of derived MCF7 breast cancer stem cells (CD44(+)/CD24 (-/low)): An in vitro study. Drug Des Devel Ther 9: 1193-1208, 2015.

29. Chang Y, Zhao Y, Gu W, Cao Y, Wang S, Pang J and Shi Y: Bufalin inhibits the differentiation and proliferation of cancer stem cells derived from primary osteosarcoma cells through Mir-148a. Cell Physiol Biochem 36: 1186-1196, 2015

30. Keysar SB and Jimeno A: More than markers: Biological significance of cancer stem cell-defining molecules. Mol Cancer Ther 9: 2450-2457, 2010.

31. White A and Swanson SJ: Minimally invasive surgery for early-stage lung cancer: From innovation to standard of care. Oncology (Williston Park) 30: 982-987, 2016

32. Gazdar AF, Girard L, Lockwood WW, Lam WL and Minna JD: Lung cancer cell lines as tools for biomedical discovery and research. J Natl Cancer Inst 102: 1310-1321, 2010.

33. Damhofer H, Ebbing EA, Steins A, Welling L, Tol JA, Krishnadath KK, van Leusden $\mathrm{T}$, van de Vijver MJ, Besselink MG, Busch OR, et al: Establishment of patient-derived xenograft models and cell lines for malignancies of the upper gastrointestinal tract. J Transl Med 13: 115, 2015.

34. Rubin H: Multistage carcinogenesis in cell culture. Dev Biol (Basel) 106: 61-67, 143-160, 2001.

35. Jones MF, Hara T, Francis P, Li XL, Bilke S, Zhu Y, Pineda M, Subramanian M, Bodmer WF and Lal A: The CDX1-microRNA-215 axis regulates colorectal cancer stem cell differentiation. Proc Natl Acad Sci USA 112: E1550-E1558, 2015.

36. Wang K, Zeng J, Luo L, Yang J, Chen J, Li B and Shen K: Identification of a cancer stem cell-like side population in the HeLa human cervical carcinoma cell line. Oncol Lett 6: 1673-1680, 2013

37. Van den Broeck A, Vankelecom H, Van Delm W, Gremeaux L, Wouters J, Allemeersch J, Govaere O, Roskams T and Topal B: Human pancreatic cancer contains a side population expressing cancer stem cell-associated and prognostic genes. PLoS One 8: e73968, 2013.

38. Chen X, Chen D, Yang S, Ma R, Pan Y, Li X and Ma S: Impact of ABCG2 polymorphisms on the clinical outcome of TKIs therapy in Chinese advanced non-small-cell lung cancer patients. Cancer Cell Int 15: 43, 2015

39. Goodell MA, Brose K, Paradis G, Conner AS and Mulligan RC: Isolation and functional properties of murine hematopoietic stem cells that are replicating in vivo. J Exp Med 183: 1797-1806, 1996.

40. Salcido CD, Larochelle A, Taylor BJ, Dunbar CE and Varticovski L: Molecular characterization of side population cells with cancer stem cell-like characteristics in small-cell lung cancer. Br J Cancer 102: 1636-1644, 2010.

41. Wu C and Alman BA: Side population cells in human cancers. Cancer Lett 268: 1-9, 2008.

42. Jiang F, Qiu Q, Khanna A, Todd NW, Deepak J, Xing L, Wang H, Liu Z, Su Y, Stass SA and Katz RL: Aldehyde dehydrogenase 1 is a tumor stem cell-associated marker in lung cancer. Mol Cancer Res 7: 330-338, 2009.

43. Liu J, Xiao Z, Wong SK, Tin VP, Ho KY, Wang J, Sham MH and Wong MP: Lung cancer tumorigenicity and drug resistance are maintained through ALDH(hi)CD44(hi) tumor initiating cells. Oncotarget 4: 1698-1711,2013.

44. Okudela K, Woo T, Mitsui H, Suzuki T, Tajiri M, Sakuma Y, Miyagi Y, Tateishi Y, Umeda S, Masuda M and Ohashi K: Downregulation of ALDH1A1 expression in non-small cell lung carcinomas-its clinicopathologic and biological significance. Int J Clin Exp Pathol 6: 1-12, 2013. 
45. Meng X, Wang X and Wang Y: More than $45 \%$ of A549 and H446 cells are cancer initiating cells: Evidence from cloning and tumorigenic analyses. Oncol Rep 21: 995-1000, 2009.

46. Willerson JT: CD133+ stem cells in the treatment of patients with refractory angina. Circ Res 120: 602-603, 2017.

47. Yi H, Cho HJ, Cho SM, Jo K, Park JA, Lee SH, Chang BJ, Kim JS and Shin HC: Effect of 5-FU and MTX on the expression of drug-resistance related cancer stem cell markers in non-small cell lung cancer cells. Korean J Physiol Pharmacol 16: 11-16, 2012.

48. Zhang HZ, Lin XG, Hua P, Wang M, Ao X, Xiong LH, Wu C and Guo JJ: The study of the tumor stem cell properties of CD133+CD44+ cells in the human lung adenocarcinoma cell lineA549. Cell Mol Biol (Noisy-le-grand) 56 (Suppl): OL1350-OL1358, 2010.

49. Roudi R, Madjd Z, Ebrahimi M, Samani FS and Samadikuchaksaraei A: CD44 and CD24 cannot act as cancer stem cell markers in human lung adenocarcinoma cell line A549. Cell Mol Biol Lett 19: 23-36, 2014.

50. Nakatsugawa $M$, Takahashi $A$, Hirohashi $Y$, Torigoe $T$, Inoda $S$, Murase M, Asanuma H, Tamura Y, Morita R, Michifuri Y, et al: SOX2 is overexpressed in stem-like cells of human lung adenocarcinoma and augments the tumorigenicity. Lab Invest 91: 1796-1804, 2011

51. Sung JM, Cho HJ, Yi H, Lee CH, Kim HS, Kim DK, Abd El-Aty AM, Kim JS, Landowski CP, Hediger MA and Shin HC: Characterization of a stem cell population in lung cancer A549 cells. Biochem Biophys Res Commun 371: 163-167, 2008.

52. Curry JM, Sprandio J, Cognetti D, Luginbuhl A, Bar-ad V, Pribitkin E and Tuluc M: Tumor microenvironment in head and neck squamous cell carcinoma. Semin Oncol 41: 217-234, 2014.

53. Kondo T: Stem cell-like cancer cells in cancer cell lines. Cancer Biomark 3: 245-250, 2007.

54. Sääf AM, Halbleib JM, Chen X, Yuen ST, Leung SY, Nelson WJ and Brown PO: Parallels between global transcriptional programs of polarizing Caco-2 intestinal epithelial cells in vitro and gene expression programs in normal colon and coloncancer. Mol Biol Cell 18: 4245-4260, 2007.

55. Klonisch T, Wiechec E, Hombach-Klonisch S, Ande SR Wesselborg S, Schulze-Osthoff K and Los M: Cancer stem cell markers in common cancers-therapeutic implications. Trends Mol Med 14: 450-460, 2008.

56. Leung EL, Fiscus RR, Tung JW, Tin VP, Cheng LC, Sihoe AD, Fink LM, Ma Y and Wong MP: Non-small cell lung cancer cells expressing CD44 are enriched for stem cell-like properties. PLoS One 5: e14062, 2010.

57. Valent P, Bonnet D, De Maria R, Lapidot T, Copland M, Melo JV, Chomienne C, Ishikawa F, Schuringa JJ, Stassi G, et al: Cancer stem cell definitions and terminology: The devil is in the details. Nat Rev Cancer 12: 767-775, 2012

58. Lin WC, Rajbhandari N and Wagner KU: Cancer cell dormancy in novel mouse models for reversible pancreatic cancer: A lingering challenge in the development of targeted therapies. Cancer Res 74: 2138-2143, 2014.

59. Williams AB: Spontaneous mutation rates come into focus in Escherichia coli. DNA Repair (Amst) 24: 73-79, 2014.

60. Le Beyec J, Xu R, Lee SY, Nelson CM, Rizki A, Alcaraz J and Bissell MJ: Cell shape regulates global histone acetylation in human mammary epithelial cells. Exp Cell Res 313: 3066-3075, 2007.

61. Gazdar AF, Gao B and Minna JD: Lung cancer cell lines: Useless artifacts or invaluable tools for medicine science? Lung Cancer 68: 309-318, 2010

62. Roschke AV, Tonon G, Gehlhaus KS, McTyre N, Bussey KJ, Lababidi S, Scudiero DA, Weinstein JN and Kirsch IR Karyotypic complexity of the NCI-60 drug-screening panel. Cancer Res 63: 8634-8647, 2003.

63. Daniel VC, Marchionni L, Hierman JS, Rhodes JT, Devereux WL, Rudin CM, Yung R, Parmigiani G, Dorsch M, Peacock CD and Watkins DN: A primary xenograft model of small-cell lung cancer reveals irreversible changes in gene expression imposed by culture in vitro. Cancer Res 69: 3364-3373, 2009.

64. Gazdar AF, Bader S, Hung J, Kishimoto Y, Sekido Y, Sugio K, Virmani A, Fleming J, Carbone DP and Minna JD: Molecular genetic changes found in human lung cancer and its precurso lesions. Cold Spring Harb Symp Quant Biol 59: 565-572, 1994.

65. Akunuru S, James Zhai Q and Zheng Y: Non-small cell lung cncer stem/progenitor cells are enriched in multiple distinct phenotypic subpopulations and exhibit plasticity. Cell Death Dis 3: e352, 2012
66. Shultz LD, Ishikawa F and Greiner DL: Humanized mice in translational biomedical research. Nature Rev Immunol 7: 118-130, 2007.

67. Perumal D, Singh S, Yoder SJ, Bloom GC and Chellappan SP: A novel five gene signature derived from stem-like side population cells predicts overall and recurrence-free survival in NSCLC. PLoS One 7: e43589, 2012.

68. Yeh CT, Su CL, Huang CY, Lin JK, Lee WH, Chang PM, Kuo YL, Liu YW, Wang LS, Wu CH, et al: A preclinical evaluation of antimycin a as a potential antilung cancer stem cell agent. Evid Based Complement Alternat Med 2013: 910451, 2013.

69. Ho MM, Ng AV, Lam S and Hung JY: Side population in human lung cancer cell lines and tumors is enriched with stem-like cancer cells. Cancer Res 67: 4827-4833, 2007.

70. Liu J, Mao Z, Huang J, Xie S, Liu T and Mao Z: Blocking the NOTCH pathway can inhibit the growth of CD133-positive A549 cells and sensitize to chemotherapy. Biochem Biophys Res Commun 444: 670-675, 2014

71. Xu Y, Jiang Z, Zhang Z, Sun N, Zhang M, Xie J, Li T, Hou Y and Wu D: HtrA1 downregulation induces cisplatin resistance in lung adenocarcinoma by promoting cancer stem cell-like properties. J Cell Biochem 115: 1112-1121, 2014.

72. Bertolini G, Roz L, Perego P, Tortoreto M, Fontanella E, Gatti L, Pratesi G, Fabbri A, Andriani F, Tinelli S, et al: Highly tumorigenic lung cancer CD133+ cells exhibit stem-like features and are spared by cisplatin treatment. Proc Natl Acad Sci USA 106: 16281-16286, 2009.

73. Yao Q, Sun JG, Ma H, Zhang AM, Lin S, Zhu CH, Zhang T and Chen ZT: Monitoring microRNAs using a molecular beacon in CD133+/CD338+ human lung adenocarcinoma-initiating A549cells. Asian Pac J Cancer Prev 15: 161-166, 2014.

74. Lin S, Sun JG, Wu JB, Long HX, Zhu CH, Xiang T, Ma H, Zhao ZQ, Yao Q, Zhang AM, et al: Aberrant microRNAs expression in $\mathrm{CD} 133^{+} / \mathrm{CD} 326^{+}$human lung adenocarcinoma initiating cells from A549. Mol Cells 33: 277-283, 2012.

75. Li Z, Xiang Y, Xiang L, Xiao Y, Li F and Hao P: ALDH maintains the stemness of lung adenoma stem cells by suppressing the notch/CDK2/CCNE pathway. PLoS One 9: e92669, 2014

76. Kim IG, Kim SY, Choi SI, Lee JH, Kim KC and Cho EW: Fibulin-3-mediated inhibition of epithelial-to-mesenchymal transition and self-renewal of ALDH+ lung cancer stem cells through IGF1R signaling. Oncogene 33: 3908-3917, 2014.

77. Zakaria N, Yusoff NM, Zakaria Z, Lim MN, Baharuddin PJ, Fakiruddin KS and Yahaya B: Human non-small cell lung cancer expresses putative cancer stem cell markers and exhibits the transcriptomic profile of multipotent cells. BMC Cancer 15: 84, 2015.

78. Ghosh G, Lian X, Kron SJ and Palecek SP: Properties of resistant cells generated from lung cancer cell lines treated with EGFR inhibitors. BMC Cancer 12: 95, 2012.

79. Levina V, Marrangoni AM, DeMarco R, Gorelik E and Lokshin AE: Drug-selected human lung cancer stem cells: Cytokine network, tumorigenic and metastatic properties. PLoS One 3: e3077, 2008

80. Shi Y, Fu X, Hua Y, Han Y, Lu Y and Wang J: The side population in human lung cancer cell line NCI-H460 is enriched in stem-like cancer cells. PLoS One 7: e33358, 2012.

81. Liu YP, Yang CJ, Huang MS, Yeh CT, Wu AT, Lee YC, Lai TC, Lee CH, Hsiao YW, Lu J, et al: Cisplatin selects for multidrug-resistant CD133+ cells in lung adenocarcinoma by activating Notch signaling. Cancer Res 73: 406-416, 2013.

82. Shien K, Toyooka S, Yamamoto H, Soh J, Jida M, Thu KL, Hashida S, Maki Y, Ichihara E, Asano H, et al:, Acquired resistance to EGFR inhibitors is associated with a manifestation of stem cell-like properties in cancer cells. Cancer Res 73: 3051-3061, 2013

83. Jaggupilli A and Elkor E: Significance of CD44 and CD24 as cancer stem cell markers: An enduring ambiguity. Clin Dev Immunol 2012: 708036, 2012.

84. Teng Y, Wang X, Wang Y and Ma D: Wnt/beta-catenin signaling regulates cancer stem cells in lung cancer A549 cells. Biochem Biophys Res Commun 392: 373-379, 2010.

This work is licensed under a Creative Commons Attribution-NonCommercial-NoDerivatives 4.0 International (CC BY-NC-ND 4.0) License. 